\title{
PREDNOSTI I NEDOSTACI ELEKTRONIČKE MALOPRODAJE U REPUBLICI HRVATSKOJ S ASPEKTA POTROŠAČA U 2020. GODINI
}

\section{ADVANTAGES AND DISADVANTAGES OF ELECTRONIC RETAIL IN CROATIA FROM THE CONSUMERS' PERSPECTIVE IN THE YEAR 2020}

SAŽETAK: Razvoj suvremene informatičko-komunikacijske tehnologije povezan s pandemijom bolesti COVID-19 uzrokovao je tektonske promjene u maloprodaji kako u svijetu tako i u Republici Hrvatskoj. Snažan rast elektroničke maloprodaje ima brojne prednosti, ali i nedostatke u odnosu na klasičnu maloprodaju u prodavaonici. Upravo je zato glavni cilj istraživanja ovog rada bio ispitati prednosti i nedostatke elektroničke maloprodaje iz perspektive potrošača u Republici Hrvatskoj. U tu svrhu provedeno je eksplorativno primarno empirijsko istraživanje putem anonimnog anketnog upitnika na uzorku od 804 ispitanika. Rezultati istraživanja upućuju na to da potrošači u Republici Hrvatskoj prepoznaju brojne prednosti kupnje putem interneta. Upravo su čimbenici praktičnosti poput uštede vremena, dostupnosti različitih proizvoda/usluga i 24-satnog radnog vremena najvažniji motivatori za korištenje ovog maloprodajnog kanala. Problemi s povratom i zamjenom naručenih proizvoda, neodgovarajući prikaz i opis ponude te nemogućnost dostave u Hrvatsku identificirani su kao najznačajniji demotivatori kod kupnje putem interneta. Zanimljivo je da pitanja sigurnosti plaćanja i zloupotrebe osobnih podataka ne utječu značajnije na odluku o kupnji. Podizanjem i unaprjeđenjem razine usluge, posebno one vezane uz kupcima najvažnije motivatore i demotivatore kupnje, moguće je značajno unaprijediti atraktivnost i konkurentnost internetskih prodavaonica u očima potrošača te time osigurati njihov uspješan daljnji razvoj i poslovanje.

KLJUČNE RIJEČI: elektronička maloprodaja, ponašanje potrošača, Hrvatska, marketing

Izv. prof. dr. sc. Ivan Kovač, Ekonomski fakultet Sveučilišta u Zagrebu, Trg J. F. Kennedyja 6, Zagreb, Hrvatska,ivan.kovac@efzg.hr

** Prof. dr. sc. Mirko Palić, Ekonomski fakultet Sveučilišta u Zagrebu, mirkopalic@gmail.com

**** Martina Hrkać, mag. oec., Ekonomski fakultet Sveučilišta u Zagrebu 


\begin{abstract}
Development of informatics and communication technology alongside with the COVID pandemics strongly contributed to the tectonic shifts in retail in the world as well as in the Republic of Croatia. Strong growth of electronic retail bears many advantages but also some disadvantages comparing to the classic retail in the store.The main goal of the research of this paper therefore was to examine the advantages and disadvantages of electronic retail from the perspective of consumers in the Republic of Croatia. For this purpose, an exploratory primary empirical study was conducted through an anonymous survey questionnaire on a sample of 804 respondents. The results of the research indicate that consumers in the Republic of Croatia recognize numerous advantages of buying online. Factors such as time savings, availability of various products/services and 24-hour availability are the most important motivators for using this retail channel. Problems with the return and replacement of ordered products, inadequate presentation and description of the offer and the impossibility of delivery to Croatia have been identified as the most significant demotivators when buying online. Interestingly, issues regarding payment security and misuse of personal data do not significantly affect the purchase decision. By raising and improving the level of service quality, especially addressing the factors related to the most important motivators and demotivators of purchases, it is possible to significantly improve the attractiveness and competitiveness of online stores in the eyes of consumers and thus ensure their successful further development and growth.
\end{abstract}

KEY WORDS: electronic retail, consumer behavior, Croatia, marketing

JEL Classification: L81, M30,

\title{
1. UVOD
}

Elektronička trgovina definira se kao proces kupnje, prodaje ili razmjene proizvoda, usluga ili informacija putem javno dostupne računalne mreže, interneta, a rezultira smanjenjem troškova i uštedom vremena (Panian, 2000). Važno je naglasiti da je elektronička trgovina više od same tehnologije, jer predstavlja poslovni model koji primjenjuje informacijske i komunikacijske tehnologije u svim aspektima proizvoda i usluga u vrijednosnom lancu (Pejić Bach, 2016.). Suvremena maloprodaja nezamisliva je bez kupnje, odnosno prodaje putem interneta. Sveprisutna digitalizacija ponajviše je doprinijela razvoju elektroničke maloprodaje, ali i trendova kao što su e-marketing, m-trgovina, primjena umjetne inteligencije i slično. Pojam elektroničke trgovine može se definirati iz četiri perspektive: komunikacijske perspektive, perspektive poslovnih procesa, perspektive pružanja usluga i virtualne perspektive (Babić i sur., 2011.). Velik broj poduzeća prepoznao je prednosti elektroničke trgovine te je ona integrirana u njihovo poslovanje. Pojavom globalne elektroničke maloprodaje pokrenute su značajne promjene u tvrtkama, tržištima te ponašanju samih potrošača. Prilagođavanje poslovnih modela i praćenje trendova u elektroničkoj maloprodaji nužno je da bi pojedino poduzeće moglo konkurirati na tržištu s obzirom na svakodnevni rast broja korisnika interneta, ali i činjenicu da je komunikacija putem interneta postala svakodnevna rutina (Aktymbayeva, i sur., 2018). U suvremenom svijetu društvene mreže kao što su Facebook i Instagram često puta predstavljaju najbolji oblik marketinga za mnoga poduzeća koja prodaju svoje proizvode i usluge. Stoga je razumno za pretpostaviti da će elektronička ma- 
loprodaja ostati najbrže rastući oblik trgovanja i u nadolazećem razdoblju. Mnoga poduzeća usmjerena na razvoj elektroničke maloprodaje, danas su profitabilna, održiva, učinkovita i inovativna. Suvremeni primjer takvih poduzeća predstavljaju Amazon, AliBaba i Ebay (Laudon i Traver, 2016). To su poduzeća koja intenzivno rade na poboljšavanju i usvajanju novih, suvremenih tehnologija i inovativnom načinu poslovanja. Elektronički trgovci na malo, sukladno navedenom, obično nemaju fizičke prodavaonice, već se isključivo bave prodajom online.

Kupovina putem interneta predstavlja virtualne prodavaonice te je danas najjednostavniji i ujedno najjeftiniji način kupovine proizvoda i usluga. Suvremena maloprodaja gotovo je nezamisliva bez elektroničke trgovine, odnosno bez kupovanja i prodavanja putem interneta. Prednosti elektroničke maloprodaje za potrošače uključuju mogućnost kupnje proizvoda ili usluge u bilo koje vrijeme, s bilo kojeg mjesta, sedam dana u tjednu, uštedu vremena, izbjegavanje gužvi, mogućnost uspoređivanja cijena proizvoda ili usluga na više mjesta, dostava na kućnu adresu i brojne druge. Kupnja je dodatno olakšana korištenjem brojnih mobilnih aplikacija (Baby, 2019). Danas je potrošačima omogućeno da uz pomoć tih aplikacija i uz samo nekoliko „klikova“ kupuju željene proizvode koristeći mobilne uređaje. Bez obzira na brojne prednosti, postoje i nedostaci vezani za elektroničku maloprodaju. Neki od značajnijih nedostataka su nemogućnost opipa proizvoda, kod potrošača se često javlja strah od krađe osobnih podataka, dodatni troškovi dostave, dugi rokovi isporuke i slično. Razumno je za pretpostaviti da su prednosti i nedostaci elektroničke trgovine od izuzetnog značaja kako za kupce tako i za prodavače, te upravo zato predstavljaju aktualnu i atraktivnu temu za istraživanje u ovome radu. Predmet rada je analiza prednosti i nedostataka elektroničke trgovine s aspekta potrošača u Republici Hrvatskoj. U fokusu je elektronička trgovina kao suvremeni način maloprodaje te prednosti i nedostaci koje proizlaze iz takvog oblika trgovine iz perspektive potrošača. Cilj je rada istražiti percepciju i stavove potrošača vezano uz prednosti i nedostatke elektroničke trgovine u RH. Naime, u radu se želi odrediti prednosti i nedostatke koje potrošači smatraju najvažnijima prilikom kupovine putem ovoga kanala prodaje. Teorijski dio rada temelji se na analizi i sintezi relevantne literature i drugih sekundarnih izvora podataka. Metode prikupljanja podataka za potrebe ovog rada temelje se na sustavnom, planskom i analitičkom prikupljanju strane i domaće literature te na interpretaciji kvantitativnih i kvalitativnih podataka raznih autora. Empirijski dio rada temelji se na primarnim podacima dobivenim istraživanjem u RH putem anketnog upitnika koji je izrađen u alatu Google Forms. Istraživanje je provedeno na uzorku od 804 ispitanika. Za interpretaciju rezultata istraživanja korištene su suvremene statističke, kao i deskriptivne metode, dok su se za donošenje vlastitih zaključaka koristile induktivne i deduktivne metode.

\section{PREGLED LITERATURE}

\subsection{Teoretski aspekti elektroničke maloprodaje}

Internet omogućava dvosmjerno komuniciranje, čime se osigurava razmjena podataka koja je krucijalna za uspješno poslovanje. Naime, na taj se način omogućava važna interakcija između kupaca i poduzeća (Chaffey, 2009). Slijedom toga, u usporedbi s tradicionalnim medijima, internetske stranice, a napose elektronička maloprodaja, pružaju mogućnost 
svakom pojedincu da bude pružatelj, ali istovremeno i primatelj sadržaja (Charlesworth, 2009). Elektronička maloprodaja omogućuje gotovo svakome da relativno jednostavno pronađe željene proizvode po najprihvatljivijoj cijeni, budući da je transparentnost i usporedba gotovo svugdje moguća (Boom, 2011). Elektroničko se poslovanje definira kao „transformacija ključnih poslovnih procesa pomoću internetske tehnologije“. Elektroničko poslovanje općenito, a posebno elektronička maloprodaja, promijenili su, pod utjecajem različitih inovacija, ne samo poslovne procese nego i cjelokupno ekonomsko okruženje u novi virtualni prostor (Pogorelova i sur., 2016). Elektroničku maloprodaju karakterizira sklapanje ugovora o kupoprodaji između trgovaca i potrošača bez fizičkog kontakta, budući da se koriste suvremene informacijske tehnologije temeljene na internetu (Amin i sur., 2016). Pojava elektroničkog tržišta bila je uvjetovana brzim i snažnim razvojem tehnologije (Janaćković i sur., 2016). Prijelaz s tradicionalnog na digitalni način poslovanja omogućio je poduzećima znatne uštede troškova i vremena. Digitalni način poslovanja olakšao je malim, srednjim i velikim poduzećima izlazak na globalno tržište, iako čimbenici kao što su socijalni, ekonomski, kulturni, pravni, tehnološki, politički znatno utječu na poslovanje u zemljama u razvoju. Prethodno navedeno posljedično otežava usvajanje novih tehnologija. Dodatno, zemlje u razvoju često se susreću s nedostatkom infrastrukture potrebne za usvajanje digitalnog načina poslovanja (Hoqe i Boateng, 2017). Vrlo je važno kontinuirano pratiti, odnosno istraživati želje i potrebe kupaca kako bi ih se moglo zadovoljiti na najbolji način, ali i kako bi se kupci trajno zadržali. Podjednako je bitno da kupci mogu biti u stalnoj interakciji s poduzećem, odnosno proizvodom koji se nudi putem elektroničke maloprodaje. Također je izuzetno važno da kupci mogu izražavati svoje mišljenje i potrebe. Na taj način proizvođači mogu dobiti informacije o željama i potrebama svojih kupaca. Dakle, veliko značenje ima ubrzana komunikacija, kao i razmjena informacija između kupaca i ponuđača proizvoda ili usluga putem interneta.

Na samu strategiju razvoja elektroničke maloprodaje utječe specifičnost pojedinih skupina proizvoda. Za digitalne su proizvode i usluge vremensko razdoblje i troškovi za izvršenje narudžbi trenutni, dok za proizvode u fizičkom obliku troškovi ovise o trajanju proizvoda, količini i brzini isporuke te kupac mora biti unaprijed obaviješten o uvjetima i troškovima dostave. Mjesto prodaje u elektroničkoj trgovini je web mjesto ili tržište na društvenim mrežama (Sairamakrishna i Lakshmi, 2019). Na taj je način omogućen pristup globalnom tržištu za kupca i prodavača. Mjesto prodaje može biti kolektivna platforma za grupu ili za više pojedinačnih prodavača. Roba i usluge mogu se nuditi po fiksnim cijenama ili putem online aukcija (npr.eBay). Poduzeća prihvaćaju nove tehnologije i na taj se način prilagođavaju ubrzanim promjenama na tržištu. Važna značajka elektroničke prodaje očituje se prije svega u maksimalnoj dostupnosti prodajnog kanala kako za kupce tako i za prodavatelje.

\subsection{Elektronička maloprodaja u svijetu}

Za razumijevanje važnosti i značaja elektroničke trgovine nužno je shvatiti glavne faktore koji su utjecali na njezin razvoj. Tu se prije svega treba spomenuti: dinamičan razvoj informatičkih tehnologija, usavršavanje telekomunikacija, integracija informatičkih i telekomunikacijskih tehnologija, svjetski procesi globalizacije i integracije, praksa međunarodnog poslovanja, viši stupanj obrazovanja stanovništva, e-poslovanje malih i srednjih poduzeća, porast trgovine uslugama,upotreba engleskog jezika, itd. (Turban, 2015). 
Promatrajući globalno tržište, od kraja 2017. godine zabilježeni su brojni pozitivni trendovi u elektroničkoj maloprodaji. Azijsko-pacifička regija ima udio od 47,5 \% elektroničke maloprodaje u ukupnoj maloprodaji, dok to u Europi iznosi 25,6 \%, a u Sjevernoj Americi $24,9 \%$. Nadalje, Kina dominira količinom prodaje u kanalu elektroničke trgovine sa 682 milijarde dolara, a slijedi je s 438 milijardi SAD (Ecommerce Foundation, 2017). Prema navedenim podacima vidljivo je da razvijenije zemlje, odnosno kontinenti imaju velike udjele elektroničke trgovine u ukupnoj maloprodaji, stoga je razumno pretpostaviti da će se taj trend nastaviti. Pojedini istraživači navode postojanje razlika među određenim skupinama zemalja u intenzitetu korištenja elektroničke maloprodaje. Manje zemlje i one na sjeveru Europe sklonije se korištenju internetskih stranica u odnosu na određene zemlje južne Europe. Primjerice u Finskoj i Švedskoj 90 \% poduzeća ima vlastite internetske stranice, dok u Italiji tek svako drugo poduzeće ima svoju internetsku stranicu (Falk i Hagsten, 2015). Prema podacima Statiste (2020) najveće prihode ostvarene od elektroničke trgovine ima Kina i predviđa se da će njezini prihodi u 2020. godini iznositi 1.115 .842 milijardi dolara.

\subsection{Elektronička maloprodaja u Republici Hrvatskoj}

Prema podacima Eurostata Hrvatska pripada skupini koja ima nizak udio stanovništva koji kupuje proizvode i usluge putem interneta u odnosu na razvijenije zemlje. Tu se prije svega misli na na zemlje kao što su Njemačka, Velika Britanija, Nizozemska i druge. U Hrvatskoj je u 2018. godini zabilježen porast upotrebe komunikacijske i informacijske tehnologije u kućanstvima, što je pozitivno utjecalo na elektroničku trgovinu. Pristup internetu u kućanstvima porastao je sa $76 \%$ u 2017. godini na $82 \%$ u 2018. godini (Eurostat, 2019). Dakle, taj se pozitivni trend nastavlja kao i 2016 godine (DZS, 2018). Putem interneta 35 $\%$ građana kupovalo je u 2018. godini, što je porast od $6 \%$ u odnosu na prethodnu godinu. U strukturi kupnje preko interneta i dalje prednjači kupnja kućnih potrepština, odjeće i sportske opreme, elektroničke opreme i dijelova za računala (Anić, 2019.). Pristup internetu glavni je čimbenik koji utječe na korištenje elektroničke trgovine. Prema navedenim podacima vidljiv je trend rasta u Hrvatskoj. Naime, kupovina putem interneta u 2018. godini bila je viša za $6 \%$ u odnosu na 2017. godinu. Unatoč tome, opseg prometa koji se ostvaruje od elektroničke maloprodaje je mali i iznosi $12 \%$ u odnosu na klasične oblike maloprodaje (Anić, 2019.).Uzimajući u obzir navedene podatke može se reći da je promet koji ostvaruje elektronička maloprodaja u Republici Hrvatskoj i udio stanovništva koji kupuje proizvode i usluge putem interneta i dalje relativno malen. No, promatrajući globalne trendove za očekivati je da će elektronička maloprodaja u Hrvatskoj također rasti.

\subsection{E-marketing}

Može se reći da je marketing u današnje vrijeme digitaliziran te se sve više poduzeća odlučuje za e-marketing s obzirom na to da svakodnevno raste broj korisnika interneta diljem svijeta. Primjerice, moderan marketing aktivno koristi rezultate znanstvenih istraživanja u području informatičke tehnologije, matematike, psihologije, fizike, kemije, kibernetike i slično te ih integrira u marketinške alate (Sriram i sur., 2019). Slijedom toga neki autori e-marketing definiraju kao marketing koji koristi razne elektroničke medije (Priansa 
i Suryawardani, 2020). Digitalno okruženje, između ostalog, omogućava korisnicima da budu uključeni u procese komunikacije kako s markom, tako i sa širom javnošću. Sve veću važnost u internetskom marketingu ima oglašavanje od „usta do usta“ (Roy i sur., 2017). Nadalje, poduzeća moraju biti u mogućnosti prilagoditi svoj asortiman mogućnostima elektroničke trgovine i novim uvjetima na tržištu, kako bi bila u stanju na najbolji mogući način zadovoljiti potrebe kupaca (Supriyati i Angelin, 2019). Suvremeni način uspješnog poslovanja karakterizira nužnost kreiranja optimalnog asortimana proizvoda i usluga, kako bi se uspješno zadovoljile potrebe što većeg broja potencijalnih kupaca. Dakle, poduzeća su prisiljena nuditi više linija, podlinija i grupa proizvoda kako bi bila uspješnija od svojih tržišnih suparnika. (Eelants, 2018). Upravo je elektronička maloprodaja prikladna za takav pristup poslovanju. Iako elektronička maloprodaja raste u odnosu na fizičku maloprodaju, stope rasta se u posljednje vrijeme usporavaju (Meeker i Wu, 2018). Društvene mreže su znatno doprinijele digitalizaciji marketinga, odnosno marketinških aktivnosti. Mnoga se poduzeća odlučuju na oglašavanje svojih proizvoda putem društvenih mreža, što je ujedno i jeftiniji način oglašavanja. Dodatni argument u prilog korištenju društvenih mreža u svrhu elektroničke kupovine je olakšana interakcija i razmjena mišljenja s potrošačima diljem svijeta. Osim toga, društvene su mreže posljednjih godina postale široko prihvaćena platforma za elektroničku maloprodaju (Yadav i Rahman, 2017).

\subsection{Umjetna inteligencija i elektronička maloprodaja}

Važno je napomenuti da danas alati i algoritmi umjetne inteligencije igraju vrlo bitnu ulogu u elektroničkoj maloprodaji. Umjetna inteligencija i strojno učenje mogu se nositi s ogromnim količinama podataka te mogu generirati visoko automatizirane procese kao što su istraživanje i upravljanje zalihama te predviđanje kupnje i potreba pojedinih skupina kupaca. Korištenje algoritma strojnog učenja umjetne inteligencije pomaže automatizirati i unaprijediti komunikaciju s kupcima (Lingam, 2018.). Umjetna inteligencija je danas postala presudna za uspjeh u elektroničkoj maloprodaji te se predviđa da će njezina uloga biti još veća. Umjetna inteligencija pomaže kupcima u donošenju odluka o kupnji, kao i praćenju proizvoda u procesu slanja i isporuke. Moderan primjer korištenja AI tehnologije je Amazonov osobni asistent Alexa, koji je integriran u Amazonove proizvode kao i u proizvode drugih proizvođača. Kupci mogu pomoću Alexe pronaći informacije o lokalnim koncertima preko eBaya, mogu vrlo lako organizirati prijevoz s jednog mjesta na drugo putem Ubera ili naručiti večeru (Kshetri, 2018.). Danas se mnogi izazovi vezani uz elektroničku maloprodaju mogu prevladati uz pomoć implementacije tehnologije umjetne inteligencije.

\section{PREDNOSTI I NEDOSTACI ELEKTRONIČKE MALOPRODAJE}

Korištenje elektroničke maloprodaje omogućuje trgovcima kreiranje pošiljki na temelju stvarnih narudžbi te na taj način mogu smanjiti troškove zaliha. Takav pristup također utječe na smanjenje troškova zaposlenih, ali i administrativnih troškova. Dodatno, maloprodaja putem interneta omogućava pojedinim poduzećima da svoju robu direktno 
plasiraju kupcima, bez uključivanja posrednika, odnosno trećih strana (Bhatti i Ur Rehman, 2019). Na taj se način smanjuju troškovi i za same prodavače, ali i za kupce, što dovodi do smanjenja krajnjih cijena zbog nižih troškova. Elektronička maloprodaja omogućava poduzećima da stvore bazu kupaca u inozemstvu bez značajnih ulaganja. No, ona im ujedno omogućava rušenje barijera koje su prisutne u tradicionalnom obliku poslovanja. Na taj se način i mala poduzeća mogu proširiti na sva tržišta diljem svijeta te postati konkurentnija (Dadić i sur., 2018). Osim navedenih prednosti elektroničke trgovine za prodavače, moguće je identificirati i njene nedostatke. Najveći problem s kojim se prodavači suočavaju odnosi se na osiguranje transakcija prilikom kupnje putem interneta. Budući da se povremeno događaju kriminalne radnje vezane za internetsku kupovinu, poduzeća neprestano rade na poboljšanju sigurnosti elektroničke trgovine. Prilikom kupnje putem interneta može doći do krađe osobnih podataka koji se upotrebljavaju za prijevare vezane uz kreditne kartice. Shodno tome, prodavačima je bitno osigurati sigurnost osobnih podataka svojih kupaca jer je sigurnost najčešći razlog odustajanja kupaca od kupovine određenih proizvoda ili usluga putem interneta. Nadalje, česta ulaganja u nove tehnologije predstavljaju generator povećanih troškova za prodavače (Jurković Majić i sur., 2015). Mnoga poduzeća, osobito manja, teško se prilagođavaju i usvajaju kontinuirano nove tehnologije potrebne za opstanak na tržištu.

Promatrajući sa strane kupca, jedna od najvećih prednosti je kupovina iz udobnosti vlastitog doma ili bilo kojeg drugog mjesta, za koju je potreban samo pristup internetu. Kupac ne mora ići iz jedne prodavaonice u drugu, već sve može kupiti s jednog mjesta. Na taj se način štedi vlastito vrijeme i novac. Uz navedeno, bitna je značajka elektroničke trgovine radno vrijeme, odnosno mogućnost kupnje proizvoda i usluga od 0 do 24 sata, 365 dana u godini, pa čak i blagdanima. Velika se prednost očituje i u bogatstvu ponude te raznolikosti proizvoda i marki, što je bitan čimbenik u privlačenju pažnje potrošača i motivaciji za kupovinu putem interneta. Proizvode se može na vrlo jednostavan način uspoređivati, za što je potrebno otvoriti svega nekoliko internetskih „,prozora“, željene proizvode odabrati i platiti (Kenneth i sur., 2015). Dokazano je da postoji pozitivan odnos između raznolikosti proizvoda i usluga te ponašanja kupaca prilikom kupnje putem interneta (Bhatti i Ur Rehman, 2019). Dakle, kupac ima mogućnost uspoređivati cijene istog ili sličnog proizvoda u različitim internetskim prodavaonicama te na taj način lako može pronaći onaj koji mu najviše odgovara. Kao što je ranije navedeno, cijene u elektroničkoj trgovini mogu značajno varirati. Na različitim internetskim stranicama mogu se pronaći različite cijene istog proizvoda ili usluge, što je za kupce značajna prednost u odnosu na tradicionalni oblik kupovanja (Sutikno i Suhartini, 2020). Upravo zbog velikog izbora i širokog asortimana u elektroničkoj trgovini, kupci se često odlučuju za „online“ kupovinu. U tradicionalnim prodavaonicama, uspoređivati cijene istih ili sličnih proizvoda nije jednostavno te iziskuje znatno više vremena. Stalna komunikacija s korisnicima i povratne informacije u vezi proizvoda, usluga, kvalitete, cijene i drugih karakteristika čine elektroničku maloprodaju često boljim rješenjem od tradicionalne prodavaonice (Bandara i suradnici, 2019). Neosporno je veliko značenje elektroničke trgovine i za kupce iz ruralnih područja i slabije razvijenih zemalja. Kupnja putem interneta omogućavala im je dostupnost proizvoda i usluga koji im ranije nisu bili mogući, ali i usavršavanje znanja iz raznih područja i zanimanja putem „online“ edukacije. U tom kontekstu treba spomenuti i olakšanu dostupnost javnih usluga kao što su obrazovanje, zdravstvo i slično. 
Kao što postoje prednosti, tako postoje i nedostaci elektroničke maloprodaje. Mnogim kupcima nedostaje fizički kontakt s prodavačem i proizvodom, zbog čega su mnogi kupci i dalje vrlo skeptični u pogledu „online“ kupovine. Kod elektroničke trgovine moguće je samo vidjeti sliku, opis proizvoda ili usluge. Dakle, nemoguće je dodirnuti, opipati proizvod prije same kupnje putem interneta (Rahman i Islam, 2018). Za mnoge je potrošače to značajan nedostatak. Nadalje kupci su zabrinuti oko toga kakav će im proizvod stići. Kupac je siguran u izgled i kvalitetu proizvoda jedino u slučaju da se radi o ponovljenoj kupnji. Proizvode koji su dostupni u elektroničkom formatu nije moguće isprobati (npr. odjeća i obuća). Također, jedna od negativnih strana elektroničke trgovine je trošak poštarine i duži rok dostave, što u pojedinim slučajevima može potrajati i do mjesec dana. Zbog dužine čekanja isporuke razina zadovoljstva kupaca može biti niža (Rahman i Islam, 2018). Mnogim kupcima predstavlja problem vraćanje i zamjena proizvoda. U slučaju tradicionalnih prodavaonica taj proces je mnogo jednostavniji, nego u slučaju „online“ kupovine. Elektronička maloprodaja temelji se na informacijskoj tehnologiji koja se neprestano mijenja i unaprjeđuje i to izuzetnom brzinom. Informacije potrebne potrošaču ponekad nisu dostupne, a u nekim slučajevima prodavači namjerno ne osiguravaju potrebne informacije, što dovodi do nedostatka transparentnosti prilikom kupnje. Navedeno je jedan od vodećih čimbenika koji dovodi do napuštanja internetske kupovine od strane kupaca (Zhou i sur., 2017). Stoga je za prodavače vrlo bitno voditi brigu o transparentnosti i dostupnosti informacija na svojim internetskim stranicama jer se pokazalo kao ključ uspješnosti u elektroničkoj maloprodaji. Kako bi stekli povjerenje svojih kupaca i kako bi zadržali stalne kupce potrebno je pružiti istinite i detaljne informacije o proizvodima i uslugama.Ukoliko bi željeli ukratko navesti nedostatke elektroničke trgovine, onda prije svega treba spomenuti sljedeće: nemogućnost provjere kvalitete proizvoda prije kupnje, vrijeme čekanja dostave proizvoda i cijena dostave te nemogućnost kupnje putem elektroničke trgovine zbog nepostojanja kontinuirane internetske povezanosti (Gahlawat, 2015). Mnoge zemlje nemaju definirane zakonske okvire za provođenje elektroničke trgovine, što poduzećima može stvarati ogromne probleme. Isto je vezano za zakonsku regulativu elektroničkog potpisa. U nekim se državama elektronički potpis ne uvažava kao dokaz. Problem zakonske regulative u Republici Hrvatskoj reguliran je Zakonom o elektroničkoj trgovini (NN 173/03, 67/08, 36/09, 130/11, 30/14, 32/19). S druge strane, zemlje Trećeg svijeta suočavaju se s digitalnim jazom koji proizlazi iz nemogućnosti nabavljanja izuzetno skupe informatičke opreme i nemogućnosti spajanja na Internet zbog zakonske regulative ili nepostojanja infrastrukture. (Rahman i Islam, 2018). Najčešće prijevare na internetu su: naplata troškova dostave (iako je prilikom kupnje naznačeno da je ona besplatna), naplaćivanje pojedinih usluga i proizvoda koji su navedeni kao besplatni, lažne aukcije u kojima kupljeni predmeti nikad ne budu isporučeni kupcu, lažni pružatelji internetskih usluga koji naplaćuju korisnicama usluge koje oni nisu koristili, poslovne franšize ili ponude koje se nude na prodaju uz preuveličane i lažne procjene zarade, razne prijevare prilikom kupnje računalnih programa i opreme itd. (Matić, 2004.). Uz navedene nedostatke, za brojne potrošače veliki problem predstavlja privatnost prilikom kupnje putem interneta. Mnogi potrošači žele izbjeći neželjenu elektroničku poštu i telemarketing. Mnoge stranice prate navike potrošača te im predlažu druge proizvode i usluge (Rahman i Islam, 2018). Prema podacima Eurostata oko 70 \% potrošača koji su sudjelovali u istraživanju o problemima prilikom kupnje putem interneta, nisu se susreli ni sa kakvim problemima. Potrošači koji su se susreli s problemima pri kupnji navode sporost dostave koja je duža od navedene (približno $20 \%$ ), tehničke probleme na internetskoj stranici prilikom 
kupnje i plaćanja (10\%) te isporuku krivih ili oštećenih proizvoda (približno $10 \%$ ) kao tri najčešća problema u internetskoj kupovini (Eurostat, 2019). S obzirom na značenje i razvoj ovog oblika maloprodaje veoma je važno kontinuirano istraživanje aktualne problematike vezano uz elektroničku trgovinu u današnjem gospodarstvu. Slijedom prethodno navedenog, u radu se detaljno istražuju prednosti i nedostaci elektroničke trgovine iz perspektive potrošača na tržištu Republike Hrvatske.

\section{CILJEVI I METODE ISTRAŽIVANJA}

Glavni cilj istraživanja ovog rada jest ispitati prednosti i nedostatke elektroničke trgovine iz perspektive potrošača u Republici Hrvatskoj. U tu svrhu provedeno je eksplorativno primarno empirijsko istraživanje putem anketnog upitnika. Cilj je bio identificirati mišljenje i stavove ispitanika o pozitivnim i negativnim stranama kupnje putem interneta. Dostupna literatura upućuje na to da su glavni motivatori za kupnju putem interneta praktičnost (kupovanje od kuće, dostupnost 0 - 24, dostava na kućnu adresu, štednja vremena, bolja mogućnost pretraživanja), veća dostupnost proizvoda i povoljnije cijene, itd. (Bhatti i Ur Rehman, 2019.; Kenneth i sur., 2015.; Sutikno i Suhartini, 2020). S druge strane glavni su nedostaci elektroničke maloprodaje vezani uz sigurnost, plaćanje unaprijed i strah od krađe podataka (Rahman i Islam, 2018.; Zhou i sur., 2017.; Gahlawat, 2015.)

Istraživanjem se željelo provjeriti jesu li najvažnije prednosti i nedostaci elektronske maloprodaje u Republici Hrvatskoj u skladu s dostupnim teorijskim okvirom. U skladu s tim postavljene su sljedeće radne hipoteze:

H1: Potrošači najčešće kupuju putem interneta zbog praktičnosti.

Praktičnost podrazumijeva dostupnost 0 - 24, mogućnost kupovanja iz vlastitog doma, mogućnost pretraživanja informacija o proizvodu/usluzi i dostavu na kućnu adresu.

H2: Potrošači ne kupuju putem interneta zbog straha za sigurnost.

Sigurnost podrazumijeva strah od krađe podataka i plaćanja usluge/proizvoda unaprijed.

H3: Pozitivniji stavovi o prednostima elektroničke maloprodaje pozitivno utječu na učestalost online kupnje.

Ispitanici koji se više slažu s pozitivnim tvrdnjama o e-trgovini češće će koristiti te usluge.

Za potrebe istraživanja korištena je tehnika prikupljanja primarnih podataka pomoću anketnog upitnika koji je izrađen u alatu Google Forms te je bio u potpunosti anoniman. Upitnik je bio sastavljen od tri dijela: (A) Demografske karakteristike, (B) Kupovne navike putem interneta i (C) Stavovi o prednostima i nedostacima e-trgovine. Sva pitanja bila su zatvorenog tipa. Prvi dio upitnika (A) odnosi se na opće podatke kao što je dob, spol i radni status. Drugi dio (B) odnosi na pitanja o učestalosti kupnje putem interneta i najčešće potrošenim iznosima. U trećem dijelu (C) nalaze se dvije skupine pitanja. Svaka se sastoji od određenog broja tvrdnji za koje su ispitanici morali na Likertovoj ljestvici navesti u kojoj se mjeri slažu ili ne slažu, gdje 1 označava najmanje slaganje (Uopće se ne slažem), a 5 najviše (U potpunosti se slažem). Prva skupina sastoji od osam tvrdnji vezanih uz prednosti e-trgovine, dok se u drugoj nalazi osam tvrdnji vezanih uz nedostatke. Upitnik je distribuiran na 
društvenim mrežama tijekom rujna i listopada 2020. godine. Radi se o neprobabilističkom prigodnom uzorku (dostupnost na društvenim mrežama), koji je jednim dijelom bio distribuiran po principu efekta snježne grude (engl. „snowball“). Ukupno 804 ispitanika su u potpunosti popunili upitnik.

Analiza rezultata napravljena je u IBM-ovu programu SPSS v.26, a za prvotnu obradu podataka korišten je Microsoft Excel 2019. Za prvi (A) i drugi (B) dio upitnika koristila se deskriptivna analiza, grafički i tablični prikazi. Za treći dio (C) korištene su deskriptivne metode za opći prikaz stavova, poput aritmetičkih sredina, medijana i moda. Faktorska analiza je korištena za istraživanje moguće grupacije tvrdnji i detektiranje strukturnih komponenti u prednostima i nedostacima e-trgovine. Nakon dobivanja povezanosti grupacija (komponenti) unutar upitnika, korišten je Spearmanov koeficijent korelacije za utvrđivanje povezanosti. Cronbachov alpha koeficijent korišten je za mjerenje pouzdanosti dviju skupina pitanja (prednosti i nedostaci). Za testiranje hipoteza, osim deskriptivne statistike, korišten je i Pearsonov hi-kvadrat test.

\section{REZULTATI ISTRAŽIVANJA}

Ukupno 804 ispitanika su do kraja popunili upitnik, a rezultati su sumirani u tablici 1. Vidljiv je veći udio žena u istraživanju, odnosno $83.5 \%$, dok udio muškaraca iznosi 16,5 $\%$.Zbog prirode dijeljenja upitnika, odnosno distribucije putem društvenih mreža, u uzorku je snažnije zastupljena mlađa populacija. Najveći broj sudionika pripada dobnoj skupini od 21 - 26 godina (26,7 \%) i 15 - 20 godina $(23,8 \%)$. Tek je 26,6 \% ispitanika starijih od 35 godina. Radni status upućuje na veliki broj studenata $(32,9 \%)$ i zaposlenih $(45,8 \%)$, zatim slijede učenici, nezaposleni te umirovljenici.

Tablica 1: Demografska obilježja ispitanika

\begin{tabular}{|c|c|c|c|}
\hline \multicolumn{2}{|l|}{$\mathrm{N}=804$} & $\mathbf{N}$ & $\%$ \\
\hline \multirow{2}{*}{ SPOL } & Muško & 133 & 16,5 \\
\hline & Žensko & 671 & 83,5 \\
\hline \multirow{5}{*}{$\begin{array}{l}\text { DOBNA } \\
\text { SKUPINA }\end{array}$} & $15-20$ & 192 & 23,9 \\
\hline & $21-26$ & 214 & 26,6 \\
\hline & $27-35$ & 184 & 22,9 \\
\hline & $35-50$ & 135 & 16,8 \\
\hline & $50+$ & 79 & 9,8 \\
\hline \multirow{5}{*}{ RADNI STATUS } & Učenik & 76 & 9,5 \\
\hline & \begin{tabular}{|l|} 
Student \\
\end{tabular} & 265 & 32,9 \\
\hline & Zaposlen/a & 368 & 45,8 \\
\hline & Nezaposlen/a & 69 & 8,6 \\
\hline & Umirovljenik & 26 & 3,2 \\
\hline
\end{tabular}


U drugom dijelu upitnika (B) istraživala se učestalost kupnje i druge navike vezane uz e-maloprodaju. Iz grafikona 1. vidljivo je da ispitanici najčešće kupuju online jednom mjesečno (55,6 \%), a druga najzastupljenija kategorija je ,jednom godišnje“ (29,7 \%). Učestalost kupnje putem interneta korištena je u kasnijoj analizi pri ispitivanju hipoteza i provjeri povezanosti prednosti i nedostataka s učestalošću kupnje. Prilikom kupnje putem interneta najveći broj ispitanika potroši od 100 - 300 kn, što spada u najmanju mjerenu kategoriju. Tek je mali broj ispitanika $(2,4 \%)$ izjavio da najčešće potroši više od 1500 kn.

Grafikon 1: Učestalost i iznos kupnje putem interneta
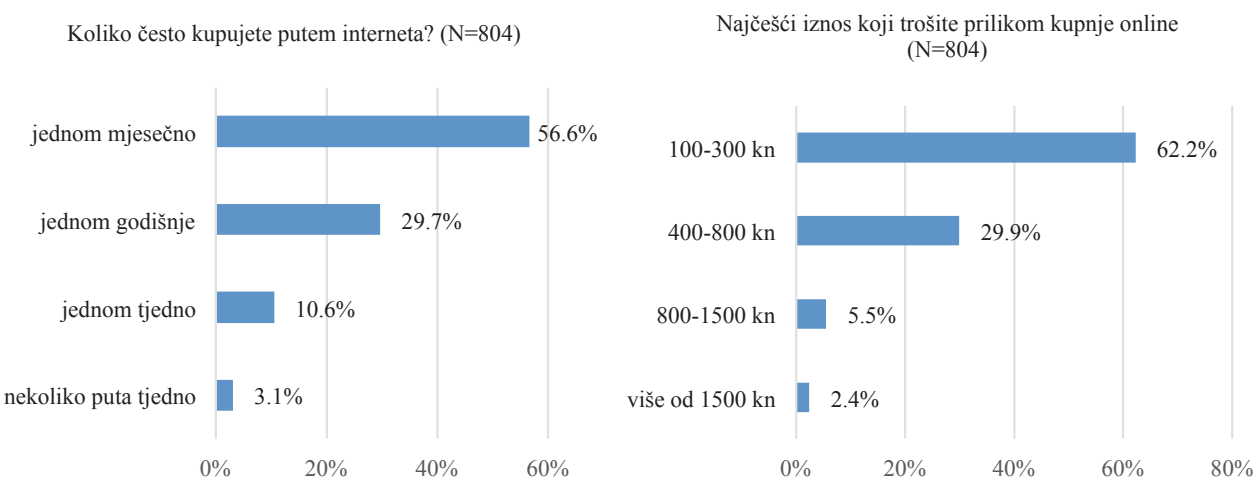

U trećem dijelu upitnika (C) ispitanici su ispred svake tvrdnje označavali stupanj slaganja, od 1 (Uopće se ne slažem) do 5 (U potpunosti se slažem). Ispitivane tvrdnje podijeljene su u dvije skupine: prva se odnosi na prednosti e-trgovine, a druga na nedostatke. Obje skupine imaju po osam tvrdnji.

U tablici 2 prikazane su aritmetičke sredine, medijan, mod i standardna devijacija za sve tvrdnje o prednostima. Poredane su prema medijanu, a zatim prema aritmetičkoj sredini. Najvišu aritmetičku sredinu ima tvrdnja na drugom mjestu, „Često kupujem putem interneta što nije dostupno u prodavaonicama“ $(4,05)$, s vrlo malom razlikom naspram tvrdnje „Veliku mi ulogu igra mogućnost kupovine 0 - 24 h gdje god se nalazim“ $(4,04)$ koja jedina u skupini ima medijan 5. Mod označava najčešći odgovor te je za gotovo sve tvrdnje jednak, 5 (U potpunosti se slažem). Iznimka je tvrdnja „E-trgovine pružaju detaljne informacije o svojim proizvodima/uslugama“ s najčešćim odgovorom (mod) 3 , koja ujedno ima i najmanju aritmetičku sredinu. 
Tablica 2: Statistički pokazatelji za prednosti e-trgovine

\begin{tabular}{|l|c|c|c|c|}
\hline \multicolumn{1}{|c|}{ Tvrdnja } & $\begin{array}{c}\text { Aritm. } \\
\text { sredina }\end{array}$ & Medijan & Mod & $\begin{array}{c}\text { Std. } \\
\text { devijacija }\end{array}$ \\
\hline $\begin{array}{l}\text { Veliku mi ulogu igra mogućnost kupovine 0 - } \\
\text { 24 h gdje god se nalazim }\end{array}$ & 4,04 & 5 & 5 & 1,21 \\
\hline $\begin{array}{l}\text { Često kupujem putem interneta što nije } \\
\text { dostupno u prodavaonicama }\end{array}$ & 4,05 & 4 & 5 & 1,12 \\
\hline $\begin{array}{l}\text { Kupnjom putem interneta štedim vlastito } \\
\text { vrijeme }\end{array}$ & 4,02 & 4 & 5 & 1,07 \\
\hline $\begin{array}{l}\text { Često pronađem jeftinije u e-trgovini nego u } \\
\text { tradicionalnoj prodavaonici }\end{array}$ & 4,01 & 4 & 5 & 1,07 \\
\hline $\begin{array}{l}\text { E-trgovine mi često nude veći izbor } \\
\text { proizvoda nego tradicionalne prodavaonice }\end{array}$ & 4,00 & 4 & 5 & 1,06 \\
\hline $\begin{array}{l}\text { Kupujem putem interneta jer mi proizvod } \\
\text { dođe na kućnu adresu }\end{array}$ & 3,96 & 4 & 5 & 1,18 \\
\hline $\begin{array}{l}\text { Prilikom kupnje proizvoda/usluge putem } \\
\text { interneta značajnu mi ulogu igraju recenzije } \\
\text { kupaca }\end{array}$ & 3,89 & 4 & 5 & 1,09 \\
\hline $\begin{array}{l}\text { E-trgovine pružaju detaljne informacije o } \\
\text { svojim proizvodima/uslugama }\end{array}$ & 3,71 & 4 & 3 & 1,02 \\
\hline
\end{tabular}

U tablici 3 prikazane su aritmetičke sredine, medijan, mod i standardna devijacija za tvrdnje o nedostacima e-trgovine. Poredane su prema medijanu, zatim prema aritmetičkoj sredini. Prema medijanu, koji označava centralnu vrijednost skupa, i modu, koji označava najčešći odgovor, ispitanike najviše brine vraćanje i zamjena proizvoda/usluge s aritmetičkom sredinom 3,67, mod 5 (U potpunosti se slažem) i medijan 4 (Slažem se). Prema istima podacima, sigurnost, odnosno strah od krađe podataka i plaćanje proizvoda/usluge ne utječe u velikoj mjeri na kupnju putem interneta. Tvrdnja „Plaćanje proizvoda/usluge unaprijed putem kupnje u e-trgovini je jedan od razloga zašto ne kupujem često putem interneta“ ima aritmetičku sredinu 2,51, medijan 2 (Ne slažem se) i mod 1 (Uopće se ne slažem), dok tvrdnja „Ne prakticiram kupnju putem interneta zbog straha od krađe podataka“ ima još nižu aritmetičku sredinu $(2,31)$ i jednak medijan $(2-$ Ne slažem se) i mod (1 - Uopće se ne slažem). 
Tablica 3: Statistički pokazatelji za nedostatke e-trgovine

\begin{tabular}{|l|c|c|c|c|}
\hline \multicolumn{1}{|c|}{ Tvrdnja } & $\begin{array}{c}\text { Aritm. } \\
\text { sredina }\end{array}$ & Medijan & Mod & $\begin{array}{c}\text { Std. } \\
\text { devijacija }\end{array}$ \\
\hline $\begin{array}{l}\text { Problem mi predstavlja vraćanje i zamjena } \\
\text { prilikom kupovine proizvoda/usluge putem } \\
\text { interneta }\end{array}$ & 3,67 & 4 & 5 & 1,30 \\
\hline $\begin{array}{l}\text { Mnoge e-trgovine ne dostavljaju svoje } \\
\text { proizvode/usluge u Republiku Hrvatsku }\end{array}$ & 3,35 & 3 & 3 & 1,23 \\
\hline $\begin{array}{l}\text { Informacije koje su navedene u e-trgovinama } \\
\text { ponekad ne odgovaraju stvarnosti (boja, } \\
\text { dimenzije i slično) }\end{array}$ & 2,93 & 3 & 3 & 1,16 \\
\hline $\begin{array}{l}\text { Prilikom kupnje proizvoda putem interneta, } \\
\text { često kvaliteta proizvoda ne odgovara onom } \\
\text { što sam očekivao/la }\end{array}$ & 2,83 & 3 & 3 & 1,12 \\
\hline $\begin{array}{l}\text { Ne kupujem učestalo putem interneta zbog } \\
\text { dugih rokova isporuke i dodatnih troškova } \\
\text { dostave }\end{array}$ & 2,75 & 3 & 2 & 1,27 \\
\hline $\begin{array}{l}\text { Stigao mi je proizvod koji nije odgovarao } \\
\text { proizvodu sa slike u e-trgovini. }\end{array}$ & 2,60 & 2 & 1 & 1,41 \\
\hline $\begin{array}{l}\text { Plaćanje proizvoda/usluge unaprijed putem } \\
\text { kupnje u e-trgovini je jedan od razloga zašto } \\
\text { ne kupujem često putem interneta }\end{array}$ & $\mathbf{2 , 5 1}$ & $\mathbf{2}$ & $\mathbf{1}$ & 1,36 \\
\hline $\begin{array}{l}\text { Ne prakticiram kupnju putem interneta zbog } \\
\text { straha od krađe podataka }\end{array}$ & $\mathbf{2 , 3 1}$ & $\mathbf{2}$ & $\mathbf{1}$ \\
\hline
\end{tabular}

U svrhu testiranja prve hipoteze, H1: Potrošači kupuju putem interneta zbog praktičnosti, analizirane su povezane tvrdnje i napravljena je faktorska analizu. Pojam praktičnost podrazumijeva dostupnost 0 - 24, dostavu na kućnu adresu i štednju vremena, stoga tu ubrajamo tvrdnje: „Veliku mi ulogu igra mogućnost kupovine 0 - 24 h gdje god se nalazim“, „Kupujem putem interneta jer mi proizvod dođe na kućnu adresu“, „E-trgovine pružaju detaljne informacije o svojim proizvodima/uslugama“ $i$,Kupnjom putem interneta štedim vlastito vrijeme“. Iz tablice 2 vidljivo je da se ispitanici s navedenim tvrdnjama slažu u visokom udjelu Mogućnost kupovine 0 - 24 h ima najviši medijan i mod (5), dok sve druge tvrdnje imaju medijan 4 , a mod 5 .

Iako su tvrdnje vezane za praktičnost prethodno definirane, faktorskom analizom provjerene su koje komponente mjerimo skupinom tvrdnji o prednostima i možemo li utvrditi da se podaci odnose na praktičnost. Provjeren je koeficijent pouzdanosti, kako bi utvrdili da se komponenta praktičnosti odnosi na navedene tvrdnje te kako bi provjerili latentne čimbenike unutar skupine pitanja. 
Tablica 4: Faktorska analiza prednosti e-trgovine (Varimax rotacija)

\begin{tabular}{|l|c|c|}
\hline N=804 & \multicolumn{2}{c|}{ Komponenta } \\
\hline \multicolumn{1}{|c|}{ Tvrdnja } & 1 & 2 \\
\hline Često pronađem jeftinije u e-trgovini nego u tradicionalnoj prodavaonici & 0,76 & \\
\hline Često kupujem putem interneta što nije dostupno u prodavaonicama & 0,72 & \\
\hline $\begin{array}{l}\text { E-trgovine mi često nude veći izbor proizvoda nego tradicionalne } \\
\text { prodavaonice }\end{array}$ & 0,67 & \\
\hline $\begin{array}{l}\text { Prilikom kupnje proizvoda/usluge putem interneta značajnu mi ulogu } \\
\text { igraju recenzije kupaca }\end{array}$ & 0,61 & \\
\hline Kupujem putem interneta jer mi proizvod dođe na kućnu adresu & & 0,81 \\
\hline Veliku mi ulogu igra mogućnost kupovine 0 - 24 h gdje god se nalazim & & 0,76 \\
\hline Kupnjom putem interneta štedim vlastito vrijeme & & 0,66 \\
\hline E-trgovine pružaju detaljne informacije o svojim proizvodima/uslugama & & 0,50 \\
\hline
\end{tabular}

Cronbachov Alpha koeficijent pouzdanosti za skupinu pitanja o prednostima e-trgovine iznosi 0,76 , što čini podatke pouzdanima i konzistentnima. Provedena su dva testa kako bi se utvrdila prikladnost podataka, odnosno može li se uopće koristiti faktorska analiza za navedenu skupinu pitanja. Kaiser-Meyer-Olkin (KMO) mjera adekvatnosti iznosi 0,79 , a Bartlettov test ljestvice očekivanja pokazuje značajnost na razini $p<0,01$, čime se potvrdilo da postoji značajna linearna korelacija između proučavanih varijabli i da su podaci prikladni za provođenje faktorske analize. Korištena je metoda glavnih komponenata (principal component), a minimalna Eigenova vrijednosti, kritična točka, postavljena je na 1. Analizom osam čestica utvrdilo se da postoje dvije vrijednosti (komponente) s kritičnom vrijednosti većom od 1 . Također, vidljivo je da dvije komponente zajedno objašnjavaju 52,2 $\%$ varijance.

U tablici 4 prikazani su rezultati varimax rotacije za tvrdnje o prednostima. Iščitavaju se dvije komponente i njihove osobine. Prva komponenta usmjerena je prema usluzi i proizvodu koji se kupuje, a druga uz proces kupovine. U prvoj komponenti nalaze se pojmovi jeftinijeg proizvoda, dostupnog proizvoda, većeg izbora proizvoda i recenzije proizvoda, stoga smo tu komponentu nazvali Kvaliteta i isplativost. Druga komponenta obuhvaća dostavu na kućnu adresu, dostupnost 0 - 24 h. štednju vremena, ali i detaljne informacije o proizvodu/ usluzi. U skladu s teorijskim okvirom, tu smo komponentu nazvali Praktičnost. U nastavku ćemo koristiti navedene čimbenike da ispitamo moguće povezanosti s učestalosti kupovine putem interneta.

U skladu s provedenim analizama i dostupnim podacima, možemo utvrditi su mjerni instrumenti praktičnosti pouzdani i možemo prihvatiti hipotezu H1: Potrošači kupuju putem interneta zbog praktičnosti.

Slijedi testiranje hipoteze H2: Potrošači ne kupuju putem interneta zbog straha za sigurnost. Pojam sigurnosti mjerili smo tvrdnjama „Ne prakticiram kupnju putem interneta zbog straha od krađe podataka“ i „Plaćanje proizvoda/usluge unaprijed putem kupnje u e-trgovini je jedan od razloga zašto ne kupujem često putem interneta“. Ispitanici su odgovarali na skali od 1 do 5 (Uopće se ne slažem - U potpunosti se slažem) i rezultati su vidljivi u tablici 3. Obje tvrdnje imaju niski medijan (2) i mod (1). Budući da odgovor 
1 označava Uopće se ne slažem, a broj 2 Ne slažem se, može se zaključiti da ispitanike ne brine sigurnost u kontekstu kupovanja putem interneta. Na temelju pregledanih statističkih podataka hipoteza H2: Potrošači ne kupuju putem interneta zbog straha za sigurnost se odbacuje.

Faktorskom analizom glavnih komponenti (Principal component) provjerena je pouzdanost skupine pitanja o nedostacima e-trgovine te koliko čimbenika postoji unutar skupine. Na početku je provjeren Cronbachov alpha koeficijent pouzdanosti za skupinu tvrdnji o nedostacima, te iznosi 0,77, što čini podatke pouzdanima i konzistentnima. Kaiser-Meyer-Olkin (KMO) mjera adekvatnosti iznosi 0,83, a Bartlettov test ljestvice očekivanja pokazuje značajnost na razini $\mathrm{p}<0,01$. U skupini o tvrdnji o nedostacima također se potvrdilo da postoji značajna linearna korelacija između proučavanih varijabli i da su podaci prikladni za provođenje faktorske analize. Za osam analiziranih tvrdnji utvrđeno je grupiranje u dvije komponente koje imaju veći kritičnu vrijednost Eigenova broja od 1. Te dvije komponente objašnjavaju 53,8 \% varijance.

Tablica 5: Faktorska analiza nedostataka e-trgovine (Varimax rotacija)

\begin{tabular}{|l|c|c|}
\hline \multicolumn{1}{|c|}{ Nvrdnja } & \multicolumn{2}{|c|}{ Komponenta } \\
\hline & 1 & 2 \\
\hline Stigao mi je proizvod koji nije odgovarao proizvodu sa slike u e-trgovini. & 0,81 & \\
\hline $\begin{array}{l}\text { Prilikom kupnje proizvoda putem interneta, često kvaliteta proizvoda ne } \\
\text { odgovara onom što sam očekivao/la }\end{array}$ & 0,77 & \\
\hline $\begin{array}{l}\text { Informacije koje su navedene u e-trgovinama ponekad ne odgovaraju } \\
\text { stvarnosti (boja, dimenzije i slično) }\end{array}$ & 0,66 & 0,47 \\
\hline $\begin{array}{l}\text { Problem mi predstavlja vraćanje i zamjena prilikom kupovine proizvoda/ } \\
\text { usluge putem interneta }\end{array}$ & 0,44 & 0,79 \\
\hline $\begin{array}{l}\text { Mnoge e-trgovine ne dostavljaju svoje proizvode/usluge u Republiku } \\
\text { Hrvatsku }\end{array}$ & 0,78 \\
\hline $\begin{array}{l}\text { Plaćanje proizvoda/usluge unaprijed putem kupnje u e-trgovini je jedan } \\
\text { od razloga zašto ne kupujem često putem interneta }\end{array}$ & 0,70 \\
\hline Ne prakticiram kupnju putem interneta zbog straha od krađe podataka \\
\hline $\begin{array}{l}\text { Ne kupujem učestalo putem interneta zbog dugih rokova isporuke i } \\
\text { dodatnih troškova dostave }\end{array}$ & & \\
\hline
\end{tabular}

Prema podacima iz tablice 5 tvrdnje vezane uz sigurnost „Ne prakticiram kupnju putem interneta zbog straha od krađe podataka“ $\mathrm{i}$ „Plaćanje proizvoda/usluge unaprijed putem kupnje u e-trgovini je jedan od razloga zašto ne kupujem često putem interneta" doista tvore istu komponentu (broj 2), ali je analiza pokazala da je tvrdnja „Ne kupujem učestalo putem interneta zbog dugih rokova isporuke i dodatnih troškova dostave“ također snažno povezana s istom komponentom. Prva komponenta je povezana uz probleme s proizvodima/ uslugama te je možemo nazvati Problemi s proizvodima, dok ćemo za prvu potvrditi naziv Sigurnost.

Posljednja hipoteza za testiranje je H3: Pozitivniji stavovi o prednostima e-trgovine pozitivno utječu na učestalost online kupovine. Kako bi provjerili što najviše utječe na 
učestalost kupnje putem interneta zbrojili smo tvrdnje unutar sve četiri komponente (Praktičnost, Kvaliteta i isplativost, Problemi s proizvodom i Sigurnost). Korišten je Spearmanov koeficijent korelacije za provjeru povezanosti jer je učestalost kupovanja putem interneta redoslijedna varijabla (odgovori su jednom godišnje, mjesečno, tjedno i par puta tjedno). Pronađena je pozitivna povezanost (tablica 6) između praktičnosti i učestalosti online kupovanja, statistički je značajna i relativno slabog intenziteta, $r_{s}=0,26, \mathrm{p}<0,01$. Provjerena je i moguća relacija između čimbenika Kvaliteta i isplativost usluge i učestalosti kupnje, te je Spearmanovim koeficijentom utvrđena neznatna pozitivna korelacija $\left(r_{s}=0,20, \mathrm{p}<0,01\right)$, kao i za povezanost Problema s proizvodom $\left(r_{s}=0,18, \mathrm{p}<0,01\right)$. Najsnažnija povezanost pronađena je između Sigurnosti i učestalosti kupovanja, no prema opće prihvaćenoj kategorizaciji jačine korelacija, još uvijek spada u relativno slabu korelaciju $\left(r_{s}=0,39, \mathrm{p}<0,01\right)$.

Hipoteza H3: Pozitivniji stavovi o prednostima e-trgovine pozitivno utječu na učestalost online kupovine se prihvaća, iako je potrebno napomenuti da je pronađena statistički značajna povezanost slabog intenziteta. Sigurnost se pokazala kao najsnažniji prediktor učestalosti kupovine putem interneta u okvirima ovog istraživanja.

Tablica 6: Povezanost komponenti prednosti i nedostataka e-trgovine s učestalošću kupovanja $\mathrm{N}=804$

\begin{tabular}{|l|c|}
\hline \multicolumn{1}{|c|}{ Komponenta } & Spearmanov koeficijent korelacije \\
\hline Praktičnost & $\mathbf{0 , 2 6 *}$ \\
\hline Kvaliteta i isplativost & $0,20 *$ \\
\hline Problemi s proizvodom & $-0,18^{*}$ \\
\hline Sigurnost & $\mathbf{- 0 , 3 9 *}$ \\
\hline
\end{tabular}

* statistički značajno, $\mathrm{p}<0,01$

\section{RASPRAVA I ZAKLJUČAK}

Primarnim istraživanjem utvrđeno je da potrošači prepoznaju mnogobrojne prednosti elektroničke trgovine na malo, odnosno snažnije percipiraju njezine prednosti nego nedostatke. Potrošači kupuju putem interneta upravo zbog brojnih čimbenika praktičnosti. Većina potrošača smatra da su najveće takve prednosti štednja vremena, 24-satna mogućnost kupnje i dostupnost proizvoda. S aspekta potrošača javljaju se i neke negativne strane elektroničke trgovine. Prema rezultatima istraživanja najveći broj ispitanika kao najveće nedostatke elektroničke maloprodaje smatra vraćanje i zamjenu proizvoda kupljenih u e-trgovini, probleme s neodgovarajućim prikazom proizvoda/usluga te elektroničke trgovine koje ne dostavljaju svoje proizvode u Republiku Hrvatsku. Strah od krađe podataka i zloupotrebe nije među vodećim detraktorima kupnje. Stoga bi poduzeća u budućnosti trebala raditi upravo na pojednostavljenju povrata i zamjene svojih proizvoda kako bi olakšala kupcima i ujedno omogućila isporuku svojih proizvoda u zemlje u koje do sada to nije bilo moguće. Drugim riječima, poduzeća bi trebala poboljšavati razinu usluge, odnosno čimbenike praktičnosti kako bi kupci bili zadovoljniji kupnjom i skloniji ponovljenim kupovinama. Glavna ograničenja ovog istraživanja proizlaze iz prigodnosti uzorka, te u velikoj nadzastupljenosti žena i mlađe populacije, što onemogućava poopćavanje podataka i donošenje zaključaka 
koji bi bili reprezentativni za cjelokupnu populaciju, odnosno cjelokupno tržište Republike Hrvatske.

\section{POPIS LITERATURE}

1. Aktymbayeva, A., Koshkimbayeva, U., Zhakupova, A., Alimgaziyeva, N. K., Amir, B. M. (2018): „E-Commerce Evaluation and E Business Trends“, International Journal of Innovative Technologies in Economy, Vol. 13, No. 2., str. 59-63.

2. Anić, I.-D. (2019): „Sektorske analize: trgovina na malo“, Sektorske analize, broj 67, godina 8, Ekonomski Institut Zagreb, Zagreb, str. 1-22.

3. Babić, R., Krajnović, A. i Radman Peša, A., 2011. Dosezi elektroničke trgovine u Hrvatskoj $i$ svijetu. Oeconomica Jadertina., str. 48- 68.

4. Bandara K., Shi, P., Christoph, B., Hewamalage, H. (2019): „Sales Demand Forecast in E-commerce using a Long Short-Term Memory Neural Network Methodology“, 26th International Conference on Neural Information Processing, Sydney, Zbornik radova, str. 462-474.

5. Baby, A. (2019): „Trends in Mobile Commerce: Benefits and Future“, Journal of The Gujarat Research Society, Vol. 21, No. 2, str. 371-402.

6. Bhat, A. S., Kansana, K., Majid J. (2016): „A Review paper on E-commerce“, (online), TIMS 2016 International Conference at Gwalior: ITM University dostupno na: https:// researchgate.net/publication/304703920 (01.02.2021.)

7. Bhatti, A., Ur Rehman, S. (2019): „Perceived benefits and perceived risks effect on online shopping behavior with the mediating role of consumer purchase intention in Pakistan“, International Journal of Management Studies, Vol. 26, No. 1, str. 33-54.

8. Boom, W. H. (2011): „Price Intransparency, Consumer Decision Making and European Consumer Law", Journal of Consumer Policy, No. 34, str. 359-376.

9. Charlesworth, A. (2009): Internet marketing: A practical Approach, Bueterworth-Heirman, Burlington, MA.

10. Dadić, M., Plazibat, I., Petričević, D. (2018): „E-Commerce: The Case Of Croatia“, Zbornik radova s konferencije Trade Perspectives 2018: Contemporary Aspects and Role of International Trade (Baković, T., Naletina, D., Knežević, B., ur.), Ekonomski fakultet, Sveučilište u Zagrebu, str. 343-354.

11. DZS, Statistički ljetopis 2018 godine, str. 308-311, dostupno na: https://www.dzs.hr/ $\mathrm{hrv} /$ publication/stat_year.htm (12.02.2021.)

12. Eelants, M. (2018): E-Commerce in the Grocery Retail Sector: The Influence of Product Category Characteristics on E-Market Shares, Master thesis, Tilburg University.

13. Ecommerce Foundation (2017): European Ecommerce Report2017, dostupno na: https://www.mirakul.hr/wp-content/uploads/2017/07/European-Ecommerce-Report-2017-draft.pdf (22. 02. 2021.)

14. Eurostat, dostupno na: https://ec.europa.eu/eurostat (14. 02. 2021.)

15. Falk, M., Hagsten, E. (2015): E-Commerce Trends and Impacts Across Europe. International Journal of Production Economics, No. 170, str. 357-369. 
16. Faraoni, M., Rialti, R., Zollo, L., Pellicelli, A. C. (2019): „Exploring e-Loyalty Antecedents in B2C e-Commerce: Empirical Results from Italian Grocery Retailers“, British Food Journal, Vol. 121, No. 2, str. 574-589.

17. Gahlawat, J. (2015): „E-commerce in modern era“, HYPERLINK “https://independent.academia.edu/IRJMSH?swp=rr-ac-19721811" International Res Jour Managt Socio Human , Vol. 6, Issue 7, str. 212-219, dostupno na: https://www.academia. edu/19721811/E-commerceinmodernera (11.01. 2021.)

18. Hoqe, M. R., Boateng, R. (2017): „Adoption of B2B e-Commerce in Developing Countries: Evidence from Ready Made Garment (RMG) Industry in Bangladesh“, Pacific Asia Journal of the Association for Information Systems, Vol. 9. No.1, 3., str. 55-74.

19. Janaćković, T., Milovanović, S., Milovanović, G. (2016): „The Transformation of Business Models and Markets in the Era of Internet and Electronic Business", Economics and Organization, Vol. 13, No. 1, str. 59 - 72.

20. Jurković Majić, O., Maras, N., Kuštrak, A. (2015): „E-commerce sales promotion and group buying concepts“, Zbornik radova sa 19th International Conference on Engineering Education. Zagreb., str. 497-504.

21. Kshetri, N. (2018): „Rural e-Commerce in Developing Countries“, IT Professional, Vol. 20, Iss. 2, IEEE, str. 91-95.

22. Laudon, K. C., Traver, C. G. (2016): E-commerce 2016: Business, Technology, Society,12. izdanje, Pearson, New York.

23. Lingam, Y. K. (2018): „The role of Artificial Intelligence (AI) in making accurate stock decisions in E-commerce industry", International Journal of Advance Research, Ideas and Innovations in Technology, Vol. 4, Iss. 3, str. 2281-2286.

24. Matić, B. (2004): Međunarodno poslovanje, Sinergija, Zagreb.

25. Meeker, M. (2018): Internet trends 2018, Kleiner Perkins, Melbourne, dostupno na: file:///C:/ Users/Mirko/Downloads/INTERNET_TRENDS_REPORT_2018.pdf (24.01. 2021.)

26. Panian, Ž., 2000. Elektroničko trgovanje. s.l: Sinergija. Zagreb

27. Pejić Bach, M., 2016. Informacijski sustavi u poslovanju. Ekonomski fakultet u Zagrebu. Zagreb.

28. Pogorelova, E. V., Yakhneeva, I. V., Agafonova, A. V., Prokubovskaya, A. O. (2016): "Marketing Mix for E-commerce“, International Journal of Environmental and Science Education, Vol. 11, Iss. 14, str. 6744-6759.

29. Priansa, D. J., Suryawardani, B. (2020): „Effects of E-Marketing and Social Media Marketing on E-commerce Shopping Decisions“, Jurnal Manajemen Indonesia, Vol. 20, Iss. 1, str. 76-82.

30. Rahman, M. A., Islam, A. (2018): „Consumer Buying Behavior Towards Online Shopping: An empirical study on Dhaka city, Bangladesh“, Cogent Business i Management, Vol. 5, Iss. 1, Taylor \& Francis, str. 1-22.

31. Roy, G., Datta, B., Basu, R., (2017): „Trends and Future Directions in Online Marketing Research“, Journal of Internet Commerce, Vol. 16, Iss. 1, str. 1-31.

32. Sairamakrishna, T., Lakshmi, P. V. (2019): E-Marketing. Complexity International Journal, Vol. 23, Issue 2., str. 225-237. 
33. Sriram, K., Phouzder, K., Mathew, A. O., Hungund, S. (2019): „Does e-marketing mix influence brand loyalty and popularity of e-commerce websites? “, ABAC Journal, Vol. 39, No. 2, str. 64-81.

34. Statista (2020): E-Commerce worldwide: Statistics \& Facts, dostupno na: https:// www.statista.com/topics/871/online-shopping/ (15. 12. 2020.)

35. Supriyati, S., Angelin, L. (2019): „Utilization of E-Commerce in Starting Titling Service“, IOP Conference Series: Materials Science and Engineering, dostupno na: https://iopscience.iop.org/article/10.1088/1757-899X/662/3/032008/pdf (12. 12. 2020.)

36. Sutikno, S. i Suhartini, S. (2020): „Price Strategies And Promotions Which E-Commerce Does In Sales“““, Primanomics: Jurnal Ekonomi Dan Bisnis, Vol. 18, No. 3 str. 113-124.

37. Turban, E., King, D., Kyu Lee, J., Liang, T. P., Turban, D.C. (2015) Electronic Commerce; A Managerial and Social Networks Perspective, Springer.

38. Yadav, M. i Rahman, Z. (2017): „Measuring Consumer Perception of Social Media Marketing activities in e-commerce industry: Scale development \& validation“, Telematics and Informatics, Vol. 34, Issue 7, November, Elsevier, str. 1294-1307.

39. Zakon o elektroničkoj trgovini, NN 173/03, 67/08, 36/09, 130/11, 30/14, 32/19 (01. 06. 2021)

40. Zhou, L., Wang, W., Xu, J., Liu, T. (2018): „Perceived Information Transparency in B2C e-commerce: An Empirical Investigation“, Information i Management, Vol. 55, Iss. 7, str. 912-927. 